\title{
Penerapan Model Concept Sentence dengan Media Flashcard untuk Meningkatkan Keterampilan Menulis Karangan pada Siswa Kelas III SD Negeri Kalikotes Tahun Ajaran 2018/2019
}

\author{
Maulida Ajeng Priyatnomo', Tri Saptuti Susiani ${ }^{2}$, Moh. Chamdani $^{3}$ \\ 1,2,2Universitas Sebelas Maret \\ maulidaajeng1@gmail.com
}

\section{Article History \\ accepted 01/10/2019}

approved 01/11/2019 published 01/12/2019

\begin{abstract}
This study aimed to describe the steps of applying the Concept Sentence model with flashcard media and improving students' essays writing skills through the application of the Concept Sentence model with flashcard media. This research is a collaborative Classroom Action Research (CAR) carried out in three cycles. The data used were quantitative data and qualitative data. Data collection techniques used observation, interviews, and tests. Data validity used techniques of triangulation and sources. Data analysis included data reduction, data presentation, and drawing conclusion. Data collection techniques used were observation, interviews, and tests. The results indicated that the application of the Concept Sentence model with flashcard media was carried out with seven steps, namely: (1) delivery of competencies to be achieved, (2) delivery of material in accordance with competencies, (3) heterogeneous group formation and sharing flashcard media, (4) presentation of keywords with flashcard, (5) making sentences with keywords on the flashcard, (6) joint discussion, and (7) conclusion. The application of the Concept Sentence learning model carried out with these steps could improve students' essays writing skills which were known through the increase of the percentage of students' completeness by $31.03 \%$ in the first cycle, $79.23 \%$ in the second cycle, and $82.79 \%$ in the third cycle.
\end{abstract}

Keywords: CS model with flashcard, essayswriting

\section{Abstrak}

Penelitian ini bertujuan untuk mendeskripsikan langkah-langkah penerapan model Concept Sentence dengan media flashcard dan meningkatkan keterampilan menulis karangan siswa melalui penerapan model Concept Sentence dengan media flashcard. Penelitian ini merupakan Penelitian Tindakan Kelas (PTK) kolaboratif yang dilaksanakan dalam tiga siklus. Data yang digunakan adalah data kuantitatif dan data kualitatif. Teknik pengumpulan data menggunakan observasi, wawancara, dan tes. Validitas data menggunakan triangulasi teknik dan sumber. Analisis data meliputi reduksi data, penyajian data, dan penarikan kesimpulan.Teknik pengumpulan data yang digunakan yaitu observasi, wawancara, dan tes. Hasil penelitian menunjukkan bahwa penerapan model Concept Sentence dengan media flashcard dilaksanakan dengan tujuh langkah yaitu: : (1) penyampaian kompetensi yang akan dicapai, (2) penyampaian materi sesuai dengan kompetensi, (3) pembentukan kelompok secara heterogen dan dan membagikan media flashcard, (4) penyajian kata kunci dengan flashcard, (5) Pembuatan kalimat dengan kata kunci yang ada di flashcard, (6) diskusi bersama, dan (7) kesimpulan. Penerapan model pembelajaran Concept Sentence yang dilakukan dengan langkah-langkah tersebut dapat meningkatkan keterampilan menulis karangan siswa yang diketahui melalui peningkatan persentase ketuntasan siswa sebesar $31,03 \%$ pada siklus I, $79,23 \%$ pada siklus II, dan $82,79 \%$ pada siklus III.

Kata Kunci: model CS dengan flashcard, menulis karangan 


\section{PENDAHULUAN}

Pembelajaran Bahasa Indonesia, terutama di sekolah dasar tidak dapat terlepas dari empat keterampilan berbahasa yaitu, keterampilan menyimak atau mendengarkan (listening skills), keterampilan berbicara (speaking skills), keterampilan membaca (reading skills), dan keterampilan menulis (writing skills). Keempat keterampilan berbahasa ini saling berkaitan satu dengan lainnya (Susanto, 2016: 241).

Keterampilan menulis adalah salah satu kemampuan yang harus dikuasai bagi peserta didik dari empat komponen yang tertera untuk berperan dalam kehidupan sehari-hari. Salah satu bagian menulis adalah menulis karangan. Manusia dengan menulis mampu mengutarakan pemikiran dan buah pikiran untuk menjangkau maksud dan tujuan. Tarigan ( $2008: 4$ ) mengatakan menulis ialah menggambarkan simbolsimbol grafis yang melukiskan suatu bahasa yang dipahami seseorang, sehingga orang lain mampu membaca simbol-simbol grafis tersebut apabila mereka memahami bahasa dan gambaran grafis tersebut. Menulis ialah tindakan yang produktif dan ekspresif. Penulis diwajibkan mampu terampil dalam menggunakan grafologi, struktur bahasa, dan kosa kata. Hal tersebut menjadi suatu kesulitan yang aplikasikan oleh siswa dalam pembelajaran Bahasa Indonesia. Permasalahan yang datang dari siswa antara lain pelatihan keterampilan menulis dan dorongan belajar menulis yang kurang, sehingga aktivitas siswa dalam belajar kurang mencapai yang diinginkan

Berdasarkan observasi dari guru pengajar kelas III SD Negeri Kalikotes ditemukan bahwa adanya kemampuan keterampilan menulis siswa yang masih kurang. Dikatakan dari guru kelas bahwa ada sebagian siswa yang sudah bisa menulis karangan, namun tidak sedikit yang belum bisa untuk menulis karangan. Hal tersebut dikarenakan kurangnya model dan media yang digunakan oleh guru kelas. Hasil belajar yang berupa karangan berdasarkan nilai rata-rata kelas III SD Negeri Kalikotes adalah 66,38 . Sebanyak $58,6 \%$ anak masih mempunyai nilai dibawah rata-rata KKM. Berdasarkan kolaborasi peneliti dengan guru kelas agar memecahkan masalah tersebut, peneliti dan guru kelas memutuskan untuk menerapkan model concept sentence berbantuan flashcard.

Model concept sentence ialah model pembelajaran yang menggunakan kartukartu yang berisi beberapa kata kunci, lalu diberikan kepada siswa. Dari kata kunci tersebut lalu disusun menjadi kalimat sampai berkembang menjadi paragraf. (Shoimin, 2014 : 37). Pembelajaran dilaksanakan yang pertama penyampaian kompetensi, sajian materi, membuat kelompok, guru mempersiapkan kata kunci sesuai materi dan kebutuhan bahan ajar, dan tiap kelompok membuat kalimat berdasarkan kata kunci yang diberikan. Tahap selanjutnya ialah mempresentasikan hasil belajar secara bergilir di depan kelas.

Tindakan menulis karangan menggunakan model concept sentence akan lebih maksimum apabila dibantu dengan media pembelajaran. Peneliti memilih media flashcard untuk menunjang pembelajaran dengan menerapkan model concept sentence. Diperkuat pendapat dari Hamer \& Rohimajaya (2018 : 168) "In flashcard, students can stimulate their imagination to develop their ideas and they can learns and find new vocabulary". Artinya bahwa di dalam flashcard siswa mampu mengembangkan imaginasi mereka dari ide dan mereka belajar dan menemukan kosa kata baru.

Berdasarkan uraian di atas, maka dapat dirumuskan masalah yaitu : 1) bagaimanakah langkah-langkah model concepts sentence? Dan 2) apakah penerapan model concept sentence dapat meningkatkan keterampilan menulis karangan siswa kelas III SD Negeri Kalikotes tahun ajaran 2018/2019?

Penelitian ini bertujuan untuk: (1) Mendeskripsikan penerapan model concept sentence dengan flashcard untuk meningkatkan keterampilan menulis karangan dan (2) meningkatkan keterampilan Meningkatkan keterampilan menulis karangan siswa pada siswa kelas III SD Negeri Kalikotes tahun ajaran 2018/2019. 


\section{METODE}

Penelitian ini merupakan penelitian tindakan kelas (PTK) kolaboratif sesuai dengan pendapat. Kunandar (2012: 44-45) bahwa Penelitian Tindakan Kelas ialah penelitian tindakan (action research) dilaksanakan oleh guru sekaligus menjadi peneliti di dalam kelasnya atau bisa bersama orang lain (kolaborasi) dengan saat merancang, melaksanakan, merefleksi tindakan dilakukan secara berkolaborasi yang bertujuan untuk memperbaiki atau meningkatkan kualitas proses pembelajaran di dalam kelas lewat suatu tindakan tertentu dalam suatu siklus. Penelitian ini menggunakan prosedur penelitian modifikasi dari Arikunto (2013: 137) yang setiap siklusnya terdiri dari tahap perencanaan, pelaksanaan, pengamatan, dan refleksi. Subjek dalam penelitian ini adalah siswa kelas III SD Negeri Kalikotes yang berjumlah 29 siswa. Data yang digunakan adalah data kuantitatif berupa nilai tes keterampilan menulis karangan dan data kualitatif berupa hasil observasi dan wawancara. Teknik pengumpulan data menggunakan observasi, wawancara, dan tes. Validitas data menggunakan triangulasi teknik dan sumber. Analisis data meliputi reduksi data, penyajian data, dan penarikan kesimpulan. Indikator kinerja penelitian ini adalah peningkatan keterampilan menulis karangan siswa dengan target $80 \%$ dan ketuntasan minimal siswa dengan target $80 \%$.

\section{HASIL DAN PEMBAHASAN}

Penelitian ini dilaksanakan selama tiga siklus dengan menerapkan tujuh langkah model model Concept Sentence dengan media flashcard dalam penelitian ini meliputi: (1) penyampaian kompetensi yang akan dicapai, (2) penyampaian materi sesuai dengan kompetensi, (3) pembentukan kelompok secara heterogen dan dan membagikan media flashcard, (4) penyajian kata kunci dengan flashcard, (5) Pembuatan kalimat dengan kata kunci yang ada di flashcard, (6) Diskusi bersama, dan (7) Kesimpulan. Langkah-langkah tersebut sesuai dengan teori menurut Shoimin (2014: 38) dan menurut Uno dan Mohammad (2012: 95).

Hasil pengamatan terhadap pelaksanaan pembelajaran bahasa Indonesia dengan menerapkan model pembelajaran Concept Sentence mengalami peningkatan pada setiap siklusnya yaitu:

Tabel 1. Persentase Hasil Pengamatan Penerapan Model Concept Sentence dengan Media Flashcard

\begin{tabular}{llll}
\hline Sumber & \multicolumn{3}{l}{ Siklus } \\
\cline { 2 - 4 } Data & I & II & III \\
Guru (\%) & 59,71 & 82,05 & 92,04 \\
Siswa (\%) & 54,30 & 82,28 & 93,42 \\
\hline
\end{tabular}

Hasil pengamatan terhadap guru pada siklus I ke siklus II meningkat sebesar $22,34 \%$ dan siklus II ke siklus III meningkat sebesar 9,99\%. Persentase rata-rata hasil pengamatan kepada siswa juga mengalami peningkatan pada siklus I ke siklus II sebesar $27,98 \%$ dan pada siklus II ke siklus III meningkat sebesar $11,14 \%$.

Hasil keterampilan menulis karangan didapat dari hasil tes yang dilakukan pada akhir pembelajaran setiap pertemuan. Analisis didapat berdasarkan jumlah persentase ketuntasan siswa. Berikut adalah hasil belajar siswa pada siklus I, II, dan III 
Tabel 2. Analisis Hasil Keterampilan Menulis Karangan Siswa

\begin{tabular}{ll}
\hline Siklus & $\begin{array}{l}\text { Persentase } \\
\text { Ketuntasan Siswa }\end{array}$ \\
\hline Siklus I & $31,03 \%$ \\
Siklus II & $79,23 \%$ \\
SIklus III & $82,79 \%$ \\
\hline
\end{tabular}

Berdasarkan data di atas, dapat diketahui bahwa persentase ketuntasan siswa pada siklus I ke siklus II meningkat sebesar $48,2 \%$ dari $31,03 \%$ menjadi $79,23 \%$ dan dari siklus II ke siklus III meningkat sebesar 3,56\% dari 79,23\% menjadi $82,79 \%$.

Berdasarkan tabel 1 dapat disimpulkan bahwa penerapan model Concept Sentence dengan Media Flashcard sudah dilaksanakan dengan baik dan sudah mencapai target indikator kinerja penelitian sebesar $80 \%$. Selanjutnya, berdasarkan tabel 2 dapat disimpulkan bahwa ketuntasan minimal siswa sudah mencapai target indikator kinerja penelitian sebesar $80 \%$.

Hal ini sejalan dengan penelitian yang dilakukan oleh Sadono, F. (2015: 22) hasil dari penerapan model concept sentence dengan media kartu dapat meningkatkan keterampilan menulis narasi siswa kelas IV-A SDN Tawangmas 01 Semarang.

\section{SIMPULAN}

Simpulan : 1) Langkah-langkah penerapan model Concept Sentence dengan media flashcard dalam penelitian ini meliputi: (1) penyampaian kompetensi yang akan dicapai, (2) penyampaian materi sesuai dengan kompetensi, (3) pembentukan kelompok secara heterogen dan dan membagikan media flashcard, (4) penyajian kata kunci dengan flashcard, (5) Pembuatan kalimat dengan kata kunci yang ada di flashcard, (6) Diskusi bersama, dan (7) Kesimpulan dan 2) penerapan model Concept Sentence dengan media flashcard dapat meningkatkan keterampilan menulis karangan yang dibuktikan dengan peningkatan nilai tes keterampilan menulis karangan pada setiap siklus. Dari hasil nilai ulangan menulis karangan, diperoleh persentase ketuntasan sebesar 41,4\%. Pada siklus I persentase ketuntasan mencapai 31,03\%. Pada siklus II persentase ketuntasan meningkat menjadi $79,23 \%$. Pada siklus III persentase ketuntasan meningkat menjadi $82,79 \%$.

\section{DAFTAR PUSTAKA}

Arikunto, S. (2013). Prosedur Penelitian. Jakarta : Rineka Cipta.

Hamer, W., \& Rohimajaya, N. A. (2018). Using Flash Card as Instructional Media to Enrich the Students' Vocabulary Mastery in Learning English. Journal of English Language Studies, 3(2), 167-177.

Huda, M.. (2013). Model-model Pengajaran dan Pembelajaran. Yogyakarta : Pustaka Belajar

Kunandar. (2012). Langkah Mudah Penelitian Tindakan Kelas. Jakarta : Rajawali Pers

Sadono, F. S. (2015). Penerapan Model Concept Sentence Dengan Media Kartu Kata Untuk Meningkatkan Keterampilan Menulis Narasi Siswa Kelas IV-A Sdn Tawangmas 01 Semarang (Doctoral dissertation, Universitas Negeri Semarang).

Shoimin, A. (2014). 68 Model Pembelajaran Inovatif dalam Kurikulum 213. Yogyakarta: Ar-Ruzz Media. 
Volume 7 Nomor 3 Tahun 2019

Susanto, A. (2016). Teori Belajar \& Pembelajaran di Sekolah Dasar. Jakarta: Prenadamedia Grup.

Tarigan, H.G. (2008). Membaca Sebagai Suatu Keterampilan Berbahasa. Bandung: Angkasa Bandung.

Uno, H.B. \& Mohammad, N. (2012). Belajar dengan Pendekatan Paikem. Jakarta : Bumi Aksara. 